\title{
HUBUNGAN PEMBERIAN ASI DAN SUSU FORMULA DENGAN STATUS GIZI BAYI USIA 0-6 BULAN
}

\author{
Eka Frelestanty ${ }^{1,2}$, Yunida Haryanti ${ }^{1,2}$ \\ ${ }^{1}$ Program Studi Kebidanan, ${ }^{2}$ Sekolah Tinggi Ilmu Kesehatan Kapuas Raya Sintan \\ Korespondensi penulis: eka.frelestanty@yahoo.com
}

\begin{abstract}
Abstrak
Latar belakang dan Tujuan: Kekurangan Gizi dapat mengakibatkan gangguan pada perkembangan dan pertumbuhan tubuh bayi dan ASI memberikan banyak manfaat pada bayi terutama nutrisi (zat gizi) dalam ASI sesuai dengan kebutuhan bayi. Masalah gizi di dunia (WHO) merupakan masalah utama yang belum terselesaikan. Kekurangan gizi mengakibatkan sekitar 35\% kematian anak balita di dunia. Secara nasional (RISKESDAS) prevalensi gizi burut-kurang di Indonesia adalah 19,6 \%. Rekapitulasi data Gizi pada tahun 2014 di wilayah kerja Puskesmas Dara Juanti Sintang yaitu, dari 420 balita dari usia 0-60 bulan dengan penilaian status gizi buruk 2,62\%, status gizi kurang $15,48 \%$, status gizi baik $80,48 \%$, status gizi lebih 1,43\%. Cakupan ASI yaitu sebesar 29,4\%. Tujuan penelitian ini ntuk mengetahui Hubungan Pemberian ASI dan Susu Formula Dengan Status Gizi Bayi Usia 0-6 Bulan di Wilayah Kerja Puskesmas Dara Juanti Kabupaten Sintang Tahun 2017”.

Metode: Jenis penelitian ini bersifat deskriftif kuantitatif dengan pendekatan cross sectional. Teknik pengambilan sampel yaitu simple random sampling dengan $\mathrm{j}$ um lah sampel 46 responden instrument penelitian menggunakan checlist.

Hasil: Hasil sebagian besar (54,3\%) bayi di berikan ASI, (45,7\%) bayi di berikan Susu Formula dan hampir seluruh bayi di kategorikan status gizi baik $(84,8 \%)$

Simpulan: Terdapat Hubungan Yang Signifikan Antara Pemberian ASI Dan Susu Formula Dengan Status Gizi Bayi Usia 0-6 Bulan Di Puskesmas Dara Juanti Sintang Tahun 2017 di peroleh hasil $p$-value $=0,002$.
\end{abstract}

Kata kunci: ASI, Status Gizi, Susu Formula

\section{Pendahuluan}

Masalah gizi di dunia merupakan masalah utama yang belum terselesaikan. Setiap tahunnya lebih dari sepertiga kematian pada anak diakibatkan karena masalah kurang gizi. Pada tahun 2010 dinegara berkembang, terdapat $18 \%$ atau 103 juta anak usia dibawah umur lima tahun (balita) mengenai gizi kurang. Permasalahan gizi kurang paling sering terjadi di Asia Selatan dan Tengah yaitu mencapai $30 \%$ didikuti oleh Asia Timur, Afrika Barat dan Timur yaitu masing-masing $22 \%, 22 \%$ dan $21 \%$ dan Asia Selatan dan Timur yaitu $17 \%$. Kekurangan gizi mengakibatkan sekitar 35\% kematian anak balita di dunia (WHO, 2010).

Epidemiologi memperlihatkan bahwa gizi kurang menyebabkan $56 \%$ kematian anak-anak di seluruh dunia dan bahwa keadaan gizi kurang, ringan, sedang, atau pun berat meningkatkan resiko kematian karena penyakit anak-anak yang biasa dengan faktor resiko relatif. Jika di bandingkan dengan mereka yang memiliki gizi yang mencukupi, orang-orang dengan status gizi yang buruk lebih cenderung mengalami penyakit diare, malaria, serta infeksi pernapasan, dan juga memiliki kemungkinan lebih besar untuk menderita semua penyakit 
ini dengan durasi waktu lebih lama (Gibney, 2009).

Berdasarkan Profil Kesehatan Indonesia 2012, berdasarkan klasifikasi Angka Kematian Bayi (AKB), menunjukkan pada tahun 2011, Myanmar merupakan negara yang memiliki AKB tertinggi di kawasan The Association of Southeast Asian Nations (ASEAN) dengan angka 47,9 per 1.000 kelahiran hidup. Empat negara termasuk Indonesia diantara Filipina, Laos dan Kamboja termasuk kelompok sedang. Sedangkan ke lima negara lainnya yaitu Singapura, Malaysia, Brunei Darussalam, Thailand dan Vietnam termasuk negara dengan AKB rendah. Tahun 2011, AKB yang dimiliki Indonesia adalah 24,8 kematian per 1.000 kelahiran hidup pada 2011. Meski AKB di Indonesia terus menurun tiap tahun, namun tingkat kematian bayi di Indonesia masih tergolong tinggi jika dibandingkan dengan negara-negara anggota ASEAN, yaitu 4,2 kali lebih tinggi dari Malaysia, 1,2 kali lebih tinggi dari Filipina, dan 2,2 kali lebih tinggi dari Thailand.

Angka Kematian Bayi adalah jumlah penduduk yang meninggal sebelum mencapai usia 1 tahun yang dinyatakan dalam 1.000 kelahiran hidup pada tahun yang sama, usia bayi merupakan kondisi yang rentan baik terhadap kesakitan maupun kematian. Menurut hasil Survei Demografi dan Kesehatan Indonesia (SDKI) terjadi penurunan $\mathrm{AKB}$ cukup tajam antara tahun 1991 sampai 2003 yaitu dari 68 per 1.000 kelahiran hidup menjadi 35 per 1.000 kelahiran hidup. Capaian AKB 32 di tahun 2012 kurang menggembirakan dibandingkan target Rencana Strategis Kementrian Kesehatan (Renstra Kemenkes) yang ingin dicapai yaitu 24 di tahun 2014 juga target Millenium Development Goals (MDG's) sebesar 23 per 1.000 kelahiran hidup di tahun 2015. Penurunan AKB yang melambat antara tahun 2003 sampai 2012 yaitu dari 35 menjadi 32 per 1.000 kelahiran hidup (Profil Kesehatan Indonesia, 2012).
Berdasarkan data Riset Kesehatan Dasar (RISKESDAS) tahun 2013, salah satu faktor penyebab AKB yaitu gizi buruk. Secara nasional, prevalensi berat-kurang pada tahun 2013 adalah 19,6 persen, terdiri dari 5,7 persen gizi buruk dan 13,9 persen gizi kurang. Jika dibandingkan dengan angka prevalensi nasional tahun 2007 (18,4 \%) dan tahun $2010(17,9 \%)$ terlihat meningkat. Perubahan terutama pada gizi buruk yaitu dari 5,4 persen tahun 2007, 4,9 persen pada tahun 2010, dan 5,7 persen tahun 2013. Sedangkan prevalensi gizi kurang naik sebesar 0,9 persen dari 2007 dan 2013. Untuk mencapai sasaran MDG's tahun 2015 yaitu 15,5 persen maka prevalensi gizi burukkurang secara nasional harus diturunkan sebesar 4,1 persen dalam periode 2013 sampai 2015. Diantara 33 provinsi di Indonesia, 18 provinsi memiliki prevalensi gizi buruk-kurang di atas angka prevalensi nasional yaitu berkisar antara 21,2 persen sampai dengan 33,1 persen. Urutan ke 19 provinsi tersebut dari yang tertinggi sampai terendah adalah Nusa Tenggara Timur, Papua Barat, Sulawesi Barat, Maluku, Kalimantan Selatan, Kalimantan Barat, Aceh, Gorontalo, Nusa Tenggara Barat, Sulawesi Selatan, Maluku Utara, Sulawesi Tengah, Sulawesi Tenggara, Kalimantan Tengah, Riau, Sumatera Utara, Papua, Sumatera Barat dan Jambi. Kalimantan Barat sendiri menempati pada urutan gizi buruk-kurang ke6 dari 19 provinsi (RISKESDAS, 2013).

Berdasarkan hasil rekapitulasi Profil Kesehatan Kabupaten Kalimantan Barat Tahun 2011, terdapat kasus gizi buruk sebanyak 294, angka tersebut didapatkan dari laporan kasus dilihat berdasarkan tandatanda klinis kasus gizi buruk. Hasil Riskesdas tahun 2010 menunjukan bahwa ditingkat nasional sudah terjadi penurunan prevalensi kurang gizi (berat badan menurut umur) pada balita dari 18,4\% tahun 2007 menjadi $17,9 \%$ tahun 2010. Penurunan terjadi pada prevalensi gizi buruk yaitu dari 5,4\% pada tahun 2007 menjadi 4,9\% pada tahun 2010. Sedang untuk prevalensi gizi kurang, pada tahun 2010 tidak terjadi 
penurunan, yaitu tetap 13,0\% (Profil Kesehatan Kabupaten Kalimantan Barat Tahun, 2011).

Sedangkan berdasarkan Profil Dinas Kesehatan Kabupaten Sintang tahun 2014, Terletak di bagian timur Propinsi Kalimantan Barat atau di antara $1^{\circ} 05^{\prime}$ Lintang Utara serta $0^{\circ} 46^{\prime}$ Lintang Selatan dan $10^{\circ} 50^{\prime}$ Bujur Timur serta $11^{\circ} 20^{\prime}$ Bujur Timur, dengan demikian Kabupaten Sintang dilalui oleh garis khatulistiwa. Luas wilayah $21.635 \mathrm{~km}^{2}$ dengan wilayah terluas terdapat di kecamatan Ambalau yaitu 6.386,40 $\mathrm{km}^{2}$ atau $29,52 \%$ sedangkan Kecamatan Sintang merupakan Kecamatan yang terkecil luas wilayah yaitu 277,05 km dari luas tersebut sebagian besar merupakan wilayah perbukitan dengan luas sekitar $13.574 \mathrm{~km}$ atau 62,74\%. Kabupaten Sintang memiliki 14 kecamatan, 189 desa/kelurahan dan memiliki 20 Puskesmas. Pada tahun 2016 di Kabupaten Sintang didapatkan status gizi pada balita/bayi sekitar $4,55 \%$ status gizi buruk, $18,75 \%$ status gizi kurang, 73,15\% status gizi baik, 3,85\% status gizi lebih (Profil Dinas Kesehatan Kabupaten Sintang tahun, 2016).

Keadaan gizi kurang banyak ditemukan bada bayi-bayi yang ibunya memilih untuk menggunakan susu formula sebagai pengganti ASI. Mereka sebenarnya tidak mampu membeli cukup susu formula untuk memberikan asupan energi yang adekuat kepada bayi-bayi merek, dengan demikian terjadilah keadaan gizi kurang. World Health Organization (WHO) dan United Nations Children's Emergency Fund (UNICEF) merekomendasikan pemberian ASI eksklusif selama sedikitnya 4 bulan sesudah bayi dilahirkan dan jika mungkin, selama 6 bulan, pemberian ASI eksklusif diartikan sebagai tindakan untuk tidak memberikan makanan atau minuman lain (bahkan air sekalipun) kecuali air susu ibu (ASI). Pemberian ASI dapat meningkatkan imunitas bayi terhadap penyakit dan insidens alergi pada bayi-bayi yang mendapat ASI ternyata lebih rendah jika dibandingkan dengan bayi-bayi yang memperoleh susu sapi (Gibney, 2009).

$$
\text { Bayi (usia 0-11 bulan) }
$$

merupakan masa pertumbuhan dan perkembangan yang pesat yang mencapai puncaknya pada usia 24 bulan, sehingga kerap diistilahkan sebagai periode emas sekaligus periode kritis. Periode emas dapat diwujudkan apabila pada masa ini bayi memperoleh asupan gizi yang sesuai untuk tumbuh kembang optimal. Sebaliknya apabila bayi pada masa ini tidak memperoleh makanan sesuai kebutuhan gizinya, maka periode emas akan berubah menjadi periode kritis yang akan mengganggu tumbuh kembang bayi dan anak, baik pada saat ini maupun masa selanjutnya. Untuk mencapai tumbuh kembang optimal, di dalam Global WHO/UNICEF merekomendasikan empat hal penting yang harus dilakukan yaitu, pertama memberikan ASI kepada bayi segera dalam waktu 30 menit setelah bayi lahir, kedua memberikan hanya ASI saja atau pemberian ASI secara eksklusif sejak lahir sampai bayi berusia 6 bulan, ketiga memberikan makanan pendamping air susu ibu (MP-ASI) sejak bayi berusia 6 bulan sampai 24 bulan, dan keempat meneruskan pemberian ASI sampai anak berusia 24 bulan atau lebih (WHO, 2010).

Sedangkan menurut Profil Puskesmas Dara Juanti tahun 2012, Jumlah penduduk di wilayah kerja Puskesmas Dara Juanti adalah 9.442 jiwa dengan luas wilayah kerja Puskesmas Dara Juanti adalah $96.250 \mathrm{~km}^{2}$ meliputi 2 Kelurahan dan 2 Desa. Puskesmas Dara Juanti terletak di dalam kota Sintang tepatnya di pinggiran kota LU $00.08322^{\circ} \mathrm{BT}$ $111.49150^{\circ}$ Ketinggian 21 M. Data yang didapatkan dari Puskesmas Dara Juanti tahun 2014 mengenai hasil pemantauan gizi didapatkan jumlah balita yang diukur sebanyak 209 balita dari 0-60 bulan dengan penilaian status gizi buruk 1,91\%, status gizi kurang $16,27 \%$, status gizi baik $79,43 \%$, dan status gizi lebih 2,39\%. Dibandingkan dengan data pada tahun 2015 mengenai hasil pemantauan status gizi tidak terjadi penurunan pada status gizi buruk dan kurang. 
Data jumlah balita yang di ukur pada tahun 2016 sebanyak 420 balita dari usia 0-60 bulan dengan penilaian status gizi buruk 2,62\%, status gizi kurang $15,48 \%$, status gizi baik $80,48 \%$, dan status gizi lebih $1,43 \%$. Mengenai status gizi bayi didapatkan jumlah bayi yang diukur sebanyak 101 bayi dari usia $0-12$ bulan dengan penilaian status gizi kurang 23,76\%, status gizi baik 76,23\%. Cakupan ASI yaitu sebesar 29,4\% (Dinas Kab.Sintang, 2015 dan Profil Puskesmas Dara Juanti).

Berdasarkan uraian di atas peneliti perlu melakukan penelitian dengan judul "Hubungan Pemberian ASI Dan Susu Formula Dengan Status Gizi Bayi Usia 0-6 Bulan di Wilayah Kerja Puskesmas Dara Juanti Kebupaten Sintang Tahun 2017”.

\section{Metode Penelitian}

Dalam penelitian ini peneliti menggunakan metode deskriptif kuantitatif desain penelian retrospektif dimana pengumpulan data di mulai dari efek atau akibat yang terjadi. Kemudian dari efek tersebut ditelusuri ke belakang tentang penyebabnya atau variabel-variabel yang mempengaruhi akibat tersebut (Notoatmodjo, 2010).

Desain penelitian ini menggunakan pendekatan retrospektif. Dimana penelitian bertolak dari efek atau variabel terikat. Kemudian dilakukan penelusuran ke belakang untuk mecari bukti-bukti pemaparan atau faktor resiko yang berhubungan dengan efek atau variabel bebasnya (Sulistyaningsih, 2011).

Populasi merupakan keseluruhan data yang diperlukan dalam suatu penelitian. Penentuan sumber data dalam suatu penelitian sangat dan menentukan keakuratan hasil penetian (Saryono, 2013).

Teknik pengembilan sampel yang digunakan adalah Simple Random Sampling karena pengambilan anggota sampel dari populasi dilakukan secara acak tanpa memperhatikan strata yang ada dalam populasi itu (Sugiyono, 2014). Dengan demikian maka peneliti memberi hak yang sama kepada setiap subjek untuk memperoleh kesempatan (Chance) dipilih menjadi sampel. Oleh karena hak setiap subjek sama, maka peneliti terlepas dari perasaan ingin mengistimewakan satu atau beberpa subjek untuk dijadikan sample (Arikuto, 20013).

\section{Hasil dan Pembahasan}

Berdasarkan tabel 1 dari 46 responden didapat hasil, sebagian besar dari responden bayinya diberikan ASI yaitu sebanyak 25 bayi $(54,3 \%)$. Berdasarkan tabel 2 dari 46 responden didapat hasil sebagian besar bayiberstatus gizi baik yaitu sebanyak 39 bayi $(84,8 \%)$.

Berdasarkan tabel 3 menunjukkan bayi yang mendapatkan ASI sejumlah 25 orang $(54,3 \%)$ tidak ada yang mengalami status gizi kurang, bayi yang mendepatkan Susu Formula sejumlah 21 orang $(45,7 \%)$ dan diantaranya mengalami gizi kurang sebanyak 7 bayi $(15,2 \%)$. Dari 46 responden 39 orang $(84,8 \%)$ mengalami status gizi baik, dan 7 orang $(15,2 \%)$ mengalami gizi kurang. Hasil uji statistik Chi Square dengan menggunakan program komputer ditunjukkan dengan nilai $p$ value $=0,002$ yang artinya ada hubungan yang signifikan antara pola nutrisi dengan status Gizi bayi umur 0-6 bulan.

Tabel 1. Distribusi Frekuensi Pemberian ASI dan Susu Formula Pada Bayi Usia 06 Bulan di Wilayah Puskesmas Dara Juanti Sintang Kabupaten Sintang Tahun 2017.

\begin{tabular}{lccc}
\hline No & Pemberian ASI dan Susu Formula & Frekuensi & Presentase \\
\hline 1 & ASI & 25 & $54,3 \%$ \\
\hline 2 & Susu Formula & 21 & $45,7 \%$ \\
\hline & Total & 46 & $100 \%$
\end{tabular}

Sumber : Data Posyandu di Wilayah Kerja Puskesmas Dara Juanti Sintang Tahun 2017 
Tabel 2. Distribusi Frekuensi Status Gizi Pada Bayi Usia 0-6 Bulan di Wilayah Puskesmas Dara Juanti Sintang Kabupaten Sintang Tahun 2017

\begin{tabular}{lccc}
\hline No & Status Gizi & Frekuensi & Presentase \\
\hline 1 & Baik & 39 & $84,8 \%$ \\
\hline 2 & Kurang & 7 & $15,2 \%$ \\
\hline & Total & 46 & $100 \%$ \\
\hline
\end{tabular}

Sumber : Data Posyandu di Wilayah Kerja Puskesmas Dara Juanti Sintang Tahun 2017

Tabel 3. Hubungan Antara ASI dan Susu Formula Dengan Status Gizi Bayi Umur 0-6 Bulan Di Wilayah Puskesmas Dara Juanti Sintang 2017

\begin{tabular}{cccccccc}
\hline Variabel & \multicolumn{4}{c}{ Status Gizi } & \multicolumn{2}{c}{ Total } & \multirow{2}{*}{ P-value } \\
\cline { 2 - 6 } & \multicolumn{2}{c}{ Baik } & \multicolumn{2}{c}{ Kurang } & & \\
\cline { 2 - 7 } & n & \% & n & \% & N & \% & 0,002 \\
\hline ASI & 25 & 54,3 & 0 & 0 & 25 & 54,3 & \\
\cline { 1 - 6 } Susu Formula & 14 & 30,4 & 7 & 15,2 & 21 & 45,7 & \\
\hline Jumlah & 39 & 84,8 & 7 & 15,2 & 46 & 100 & 0,002
\end{tabular}

Sumber : Data Posyandu di Wilayah Kerja Puskesmas Dara Juanti Sintang Tahun 2017

a. Pemberian ASI Dan Susu Formula Pada Bayi 0-6 Bulan di Wilayah Kerja Puskesmas Dara Juanti Sintang

Hasil penelitian diperoleh sebagian besar bayi 0-6 bulan diberikan ASI yaitu sebanyak 25 bayi (54,3\%). Namun demikian masih ada sebagian bayi yang diberikan susu formula yaitu sebanyak 21 $(45,7 \%)$ dikarenakan ibu berkerja dan tidak keluarnya ASI dari payudara ibu sehingga bayi membutuhkan makanan lebih, dan ibu memberikan susu formula kepada bayi mereka.

Menurut Sibagariang (2010) ASI satusatunya makanan dan minuman diperlukan oleh seorang bayi dalam enam bulan pertama. Tidak ada makanan atau minuman lain, termasuk air putih, yang diperlukan selama periode ini. Susu hewan, susu formula, susu bubuk, teh, minuman yang mengandung gula, air putih, pisang, dan padi-padi tidak memiliki kandungan sebaik ASI. ASI adalah makanan yang bergizi dan berkalori tinggi, yang mudah untuk dicerna. ASI memiliki kandungan yang membantu penyerapan nutrisi, membantu perkembangan dan pertumbuhannya, juga mengandung sel-sel darah putih, antibodi, anti peradangan dan zat-zat biologi aktif yang penting bagi tubuh bayi dan melindungi bayi dari berbagai penyakit.

Penelitian yang mendukung adalah penelitian yang dilakukan oleh Enung Mardiyana Hidayat mengenai Hubungan Pola Pemberian Nutrisi saat Bayi Berusia 0-6 bulan dengan Status Gizi Bayi di Wilayah Kerja Puskesmas Kenjeran Surabaya Tahun 2009, sebagian besar bayi umur 0-6 bulan mengkonsumsi ASI sebanyak $(53,65 \%)$

b. Gambaran status gizi bayi umur 0-6 bulan di wilayah kerja Puskesmas Dara Juanti Kabupaten Sintang

Hasil penelitian diperoleh sebagian besar bayi 0-6 bulan didapat hasil sebagian besar bayi berstatus gizi baik yaitu sebanyak 39 bayi $(84,8 \%)$. Bayi yang mendapatkan status gizi baik tidak terlepas dari kebutuhan nutri yang terpenuhi bayi memerlukan nutrisi yang sesuai menurut usia untuk mencapai tumbuh kembang yang baik.

Menurut Siagian (2010) makanan sehari-hari yang dipilih dengan baik akan memberikan semua zat gizi yang dibutuhkan untuk fungsi normal tubuh. Sebaliknya, bila makanan tidak dipilih dengan baik, tubuh 
akan mengalami kekurangan zat-zat gizi esensial tertentu. Zat gizi esensial adalah zat gizi yang didatangkan dari makanan.

Penelitian yang mendukung adalah penelitian yang dilakukan oleh Agustina Kristiani Purwanti mengenai Perbedaan Status Gizi Bayi Umur 0-6 Bulan Antara Bayi Yang Mendapatkan ASI Dengan Bayi Yang Mendapatkan ASI dan Susu Formula Di Kelurahan Dusun Sidomukti Kotamadya Salatiga, sebagian besar bayi umur 0-6 bulan berstatus gizi baik sebesar $(83,87 \%)$.

c. Hubungan pemberian ASI dan susu formula dengan status gizi bayi umur 0-6 bulan di Wilayah Kerja Puskesmas Dara Juanti Kabupaten Sintang

Dari data pada tabel 3 diketahui bayi yang mendapatkan ASI dan berstatus gizi baik yaitu 25 bayi $(54,3 \%)$ dikarenakan ASI memiliki unsur-unsur yang memenuhi semua kebutuhan bayi akan nutrien selama periode sekitar 6 bulan, komposisi ASI akan berubah sejalan dengan kebutuhan bayi oleh karena itu bayi-bayi yang mendapat ASI secara penuh jarang terjangkit oleh penyakit yang dapat menurunkan status gizi bayi. Menurut Heryati (2005) ASI adalah makanan terbaik untuk bayi tidak ada sutu pun makanan lain yang dapat menggantikan ASI, karena ASI mempunyai kelebihan yang meliputi 3 aspek yaitu aspek gizi, aspek kekebalan dan aspek kejiwaan.

Bayi yang mendapatkan susu formula dan berstatus gizi buruk yaitu sebanyak 7 bayi $(15,2 \%)$ hal ini dikarenakan konsumsi gizi yang tidak mencukupi kebutuhannya dalam waktu tertentu. Namun demikian bayi yang mendapatkan susu formula dan berstatus gizi baik yaitu 14 bayi $(30,4)$ disebabkan karena asupan nutrisi yang didapatkan bayi tercukupi dan pemberian susu formula sesuai dengan kebutuhan tubuh bayi.

Hasil dari analisis uji statistik dengan menggunakan Chi-squre didapatkan nilai $P$ Value $=0,002<\alpha(0,05)$ dengan demikian Ho ditolak dan Ha diterima artinya ada hubungan yang signifikan antara ASI dan susu formula dengan status gizi bayi umur
0-6 bulan di wilayah Puskesmas Dara Juanti Sintang. Hal ini sejalan dengan pendapat Supariasa (2014), yang mengatakan bahwa Gizi adalah merupakan suatu proses organisme menggunakan pola nutrisi yang dikonsumsi secara normal melalui proses digesti, absorbsi, transportasi, penyimpanan, metabolisme dan pengeluaran zat-zat yang tidak digunakan untuk mempertahankan kehidupan pertumbuhan dan fungsi normal dari organ-organ serta menghasilkan energi. Terjadinya krisis ekonomi, politik dan sosial termasuk bencana alam yang mempengaruhi ketidakseimbangan antara asupan makanan dan adanya penyakit infeksi yang pada akhirnya mempengaruhi status gizi bayi. Kekurangan gizi secara umum menyebabkan gangguan pada proses pertumbuhan, produksi tenaga, pertahanan tubuh, prilaku, struktur dan fungsi otak, maka dari itu semakin bertambah usia bayi maka makin bertambah pula kebutuhannya. Menurut Arisman (2009) komsumsi makanan berpengaruh terhadap status gizi seseorang, status gizi optimal terjadi bila tubuh memperoleh cukup zat-zat gizi yang digunakan secara efesien, sehingga memungkinkan pertumbuhan fisik, perkembangan otak, kemampuan kerja dan kesehatan secara umum pada tingkat setinggi mungkin.

Penelitian ini sesuai dengan penelitian sebelumnya yang diteliti oleh Viora Valentina Assa dengan judul "Hubungan antara Pola Nutrisi dan Status Gizi Bayi umur 0-6 bulan di Puskesmas Rawak Kabupaten Sekadau Tahun 2017". Penelitian tersebut merupakan penelitian observasional analitik dengan rancangan cross sectional, dari 31 responden didapatkan hasil sebagian besar $(61,31 \%)$ bayi yang diberikan ASI ekslusif, $(29,0 \%)$ Bayi yang diberikan ASI kombinasi, $(9,7 \%)$ bayi yang diberikan susu formula dan hampir seluruh bayi $(90,3 \%)$ dikatagorikan status gizi baik, serta adanya hubungan yang signifikan $\left(\mathrm{X}^{2}=\right.$ $8,119 p$-Value $=.0,017$ ). 


\section{Simpulan}

Setelah dilakukan penelitian di Wilayah Puskesmas Dara Juanti Sintang terhadap 46 bayi berusia 0-6 bulan dapat disimpulakan bahwa Pemberian ASI dan susu formula pada bayi usia 0-6 bulandi Wilayah Kerja Puskesmas Dara Juanti Sintang sebagian besar diberikan ASI yaitu sebanyak 25 bayi $(54,3 \%)$ dengan status gizi sebagian besar berstatus gizi baik sebanyak 39 bayi $(84,8 \%)$ serta ada hubungan yang signifikan antara ASI dan susu formula dengan status gizi bayi usia 0-6 bulan di Wilayah Kerja Puskesmas Dara Juanti Sintang dengan $p$ value $=0,002$.

\section{Referensi}

Arikunto, Suharsimi. 2013. Prosedur Penelitian Satuan Pendekatan Praktik. Jakarta: Renika Cipta

Arisman, MB .2014. Gizi dalam Daur Kehidupan.Jakarta: EGC

Arikunto, Suharsimi, 2010. Prosedur Penelitian Suatu Pendekatan Praktek. Edisi Revisi, Jakarta: Rineka Cipta.

Deparemen Gizi dan Kesehatan Masyarakat FKM- U. 2014. Gizi dan Kesehatan Masyarakat. Edisi Revisi, Jakarta: Rajadrafindo Persada

Dinas Kesehatan Provensi Kalbar. 2011. Profil Kesehatan Provensi Kalimantan Barat Tahun 2011. Melalui<www.depkes.go.id/reso \begin{tabular}{lr}
\hline urces/.../profil/ & PROFIL. \\
\hline .P.Prov.KALBAR & 201
\end{tabular} 1.pdf>[29/03/20 15]

Dinas Kesehatan Kabupaten Sintang. 2014. Profil Dinas Kesehatan Kabupaten Sintang tahun, 2014. Sintang: Dinas Kesehatan Sintang

Febry, Ayu Bulan. 2008. Buku Pintar Menu Bayi, Jakarta: Rahayu Media. Melalui <https://books.google.co.id/books?id= ffbYsH0m49QC\&pg=PT 1 $8 \& \mathrm{dq}=\mathrm{JE}$ NIS+JENIS+SUSU+FORMULA\&hl $=\mathrm{id} \& \mathrm{sa}=\mathrm{X} \& \mathrm{ei}=\mathrm{Sro}$

VYGdKorl8gW6

74GwDw\&ved=0CCUQ6AEwAA \#v=onepage\&q=JENIS\%20JENIS \% 20SUSU\%20FOR

MULA\&f=false $>$ [ 29/03/2015]

Gibney Michael J, dkk . 2009.

Gizi Kesehatan

Masyarakat. Jakarta:

EGC Heryanti, dkk.

2005. Gizi Dalam

Kesehatan

Reproduksi.Jakarta:

EGC Hayati, Aslis

Wirda. 2009. Buku

Saku Gizi Bayi.

Jakarta: EGC

Kementrian Kesehatan RI. 2012. Profil

Kesehatan Indonesia 2012. Jakarta: Kementrian Kesehatan RI.

Melalui <http://www.depkes.go. id/resources/

download/pusdatin/profil-kesehatanindonesia/profil-kesehatanindonesia2012.pdf> [29/3/2015]

Mirayanti, Niketut Ayu. 2012. Hubungan Pola Asuh Pemenuhan Nutrisi dalam Keluarga Pasir Gunung Selatan Kecamatan Cimanggis Kota Depok. Melalui $\leq$ lib.ui.ac.id/file?file = digital/2030 9760...\%20Hubungan\%20pola.pdf >. [18/3/2015]

Miskey, D. 2009. Memiliki Balita Sehat dan Cerdas. Beranda Media Ilmu. Jakarta

Notoatmodjo, Soekidjo. 2010. Metode Penelitian Kesehatan. Edisi Revisi, Jakarta: Rineka Cipta.

Puskesmas Dara Juanti.2014.

Profil Puskesmas Dara

Juanti: Kab.Sintang.

Roesli, U. 2007.

Mengenal ASI

Eksklusif. Jakarta:

Trubus Agriwijaya

Sandjaja,dkk. 2010.

Kamus Gizi. Jakarta:

Kompas 
Siagian, Albiner. 2010. Epidemologi Gizi.

Jakarta: Erlangga

Soekirman. 2009. Status Gizi dan Faktor yang Mempengaruhi. Melalui <http://anwarsasake.wordpress.com/ 2009.08/07status-gizi-danfaktoryangmempengaruhi/ $>[02 / 9 / 2015]$

Sibagariang, Eva Ellya.2010. Gizi Kesehatan Reproduksi.Jakarta: Trans Info Media

Sulistyaningsih. 2011. Metodologi Penelitian Kebidanan KuantitatifKualitatif. Yogyakarta: Graha Ilmu Wibowo, adik. 2014. Metodologi Penelitian Paktis. Jakarta: Rajagrafindo Persada Yuniastuti, Ari. 2008. Gizi dan Kesehatan. Yogyakarta: Graha Ilmu 
e-ISSN : 2614-5685

p-ISSN : 2614-5421 